\title{
Psychology of Literature and Literature in Psychology
}

\author{
Rosemary Conceição dos Santos ${ }^{1, *}$ \\ Orcid.org/0000-0001-7304-0511 \\ João Camilo dos Santos ${ }^{2}$ \\ Orcid.org/0000-0001-9967-9946 \\ José Aparecido da Silva ${ }^{3}$ \\ Orcid.org/0000-0002-1852-369X
}

\author{
${ }^{1}$ Universidade de São Paulo, São Paulo, Brasil \\ ${ }^{2}$ University of California, Santa Bárbara, EUA \\ ${ }^{3}$ Universidade de São Paulo, Ribeirão Preto, Brasil
}

\begin{abstract}
This paper performs the reading the thematic relationship established between Psychology and Literature in two perspectives: through the considerations set out in Literary Studies by René Wellek and Austin Warren (Psychology of Literature) and Psychological Studies by Dante Moreira Leite (Psychology in Literature). The first one deals with the psychological study of the writer as an individual and the type or types and laws present in literary works, in the second, psychology as a perspective for the teaching of literature, the creative process, the psychological analysis of text and reader relationships with your audience. $\mathrm{O}$ article presents the partial results obtained from the development of literature necessary to the course called the Psychology of Literature and Psychology in Literature, taught at the 43rd Annual Meeting of the Society of Psychologists in Aracaju (Sergipe), in 2013. It also presents the detailed schematization of the reading process observed in the textual reception process and in the organism-environment interaction.
\end{abstract}

Keywords: Literature and Psychology, interdisciplinary, perspective.

\section{Psicologia da Literatura e Psicologia na Literatura}

\section{Resumo}

Este trabalho efetua a leitura da relação temática que se estabelece entre Psicologia e Literatura em duas perspectivas: através das considerações estabelecidas nos Estudos Literários por René Wellek e Austin Warren (Psicologia da Literatura) e nos Estudos Psicológicos por Dante Moreira Leite (Psicologia na Literatura). Na primeira, ocupa-se do estudo psicológico do escritor como tipo ou indivíduo e dos tipos e das leis presentes em obras literárias; na segunda, da Psicologia como perspectiva para a recepção da Literatura, do processo criador, da análise psicológica do texto e das relações do leitor com seu público. $\mathrm{O}$ artigo apresenta os resultados parciais obtidos com o desenvolvimento da pesquisa bibliográfica ne-

* Mailing address: Universidade de São Paulo, Faculdade de Filosofia Letras e Ciências Humanas, Av. Prof. Luciano Gualberto, 403, Butantã, São Paulo, SP, Brazil 05508-900. Phone: (16) 99786-4788. E-mail: cienciausp@usp.br 
cessária ao curso denominado Psicologia da Literatura e Psicologia na Literatura, ministrado na $43^{\mathrm{a}}$ Reunião Anual da Sociedade Brasileira de Psicologia, em Aracaju (Sergipe), em 2013. Apresenta, também, a esquematização detalhada do processo de leitura observada no processo de recepção textual e na interação organismo-ambiente.

Palavras-chave: Psicologia e Literatura, interdisciplinaridade, perspectiva.

\section{Psicología de la Literatura y Literatura en Psicología}

\section{Resumen}

En este trabajo se realiza la lectura de la relación temática que se establece entre la psicología y la literatura en dos perspectivas: através de las consideraciones expuestas en Estudios Literarios de René Wellek y Austin Warren (Psicología de la Literatura) y Estudios Psicológicos de Dante Moreira Leite (Psicología de Literatura). La primera se ocupa del estudio psicológico del escritor como un individuo y el tipo o los tipos y las leyes actuales sobre las obras literarias, en el segundo, la psicología como una perspectiva para la enseñanza de la literatura, el proceso creativo, el análisis psicológico de texto y relaciones del lector con su público. $\mathrm{O}$ artículo presenta los resultados parciales obtenidos en el desarrollo de la literatura necesaria para el curso llamada la Psicología de la Literatura y Psicología en literatura, ha enseñado en la 43ª Reunión anual de la Sociedad de Psicólogos en Aracaju (Sergipe), en 2013. Se presenta, también, la esquematización detallada del proceso de lectura observada en el proceso de recepción textual y en la interacción organismo-ambiente.

Palabras clave: Literatura y Psicología, interdisciplinarios, perspectiva.

\section{Psychology and Literature: An Interdisciplinary Relationship}

By understanding interdisciplinarity as the proximity established by fields of knowledge with one another in order to exceed the discoursive principles of one field in the intersection with the theoretical perspectives and functioning modes of the other, it can be seen that interdisciplinarity is opportune for the break of the specialized character of the disciplines, a break that can be verified on different levels and in different degrees (Pombo, 2005). This opportunity arises, of course, without detracting from any of the advances that interdisciplinary studies have made possible for mankind, but rather in an attempt to reverse the situation of modern man, and of specialists in particular, whereby one understands increasingly more about increasingly less, especially at present, when in general the new open access media make available to everybody, without distinction, all the world knowledge with a simple touch on a liquid crystal screen. Within this context, what is the proxim- ity of Psychology, which deals with specificities such as knowing and interpreting human beings and the world, to Literature, which deals with the possibility of imagination freeing itself from rules?

Psychology values logic, a situation that is substantially opposed to Literature, even though the latter may be based on likelihood. According to Russell (1964, p. 551), "Psychologists prefer observations that can be replicated, whereas a serious writer deals with analogy, metaphor, and perhaps intentional ambiguity". Nevertheless, both share the objective of understanding the development of their subjects, real/fictional characters, respectively, through the conflicts and problems they face in life or in the plot. This quality, again according to Russel, leads to the fact that knowledge of one field can contribute to the other in at least four categories: the psychology of the writer, the psychology of the creative process, the study of behavior, and the responses to literature.

In the psychology of the writer there is the presence of the psychological interpretation of 
biographies and autobiographies of other writers, which help him learn about the authors. In turn, the psychology of the creative process focuses both on the personality of the writer and of his characters regarding how the latter function (i.e., whether they are corrected, rewritten and and reelaborated according to the change of the way of being of their creator). Psychological studies of the process of creation of literary works usually involve the stages that all creative processes go through, respecting the peculiar variations in the style of each author. Within this context, based on psychological logic, the study of the behavior described seeks to delineate the character and the registration of the attitudes that human subjects make explicit or leave implied when performing them. Similarly, the readers also respond, in their own way, to what they read, a fact that renders the responses to literature "effects" that determined plots have on the readers.

On an interdisciplinary basis, Psychology, as is the case for the perspective of related disciplines such as History, Linguistics, Communication, Social Sciences, Philosophy, Education, and Arts (Visual Arts, Music, Theater, Cinema), among others, in an attempt to establish the degree of relationship between a work of art and what surrounds it in order to provide human enligthenment, permits the extrinsic study of literature (i.e., a study whose perspective or focus is not directed at literary essence, but rather at a point outside it through which it is contextualized and interpreted). In this endeavor, those who study this topic, such as Leite (2003) and Wellek and Warren (1949), in an attempt to contribute to the understanding of this relationship, have tried to clarify what the relationship between psychology and literature deals with, describing its reach and its fragilities.

René Wellek and Austin Warren (1949, p. 95) have defined the expression "psychology of literature" as (a) the psychological study of the writer as a type and an individual, (b) the study of the creative process, (c) the study of the types and laws that are present in literary works, and (d) the study of the effects of literature on the readers. According to these authors, the psy- cholgical study of a writer as an individual and a type, as well as the study of his creative process, is an action of interest for the Psychology of Art, an area of Psychology that describes and explains the psychological experience of a being in the behaviors related to art, either by appreciating, creating and executing it or by interacting with the public and listening to their criticisms.

\section{Psychology of Literature}

\section{The Psychological Study of the Writer as a Type and an Individual}

The study of how people think, act, influence and relate to each other is part of the context of Social Psychology, a branch of Psychology that, in the 20th century, has been devoted to an attempt to dialogue with the Social Sciences, also dealing with the social experience acquired by the individuals who participate in different social movements. Within the first context, Krech and Crutchfield (1973, p. 13) stated that denominations of the following type: "manwho-perceives", "man-who-needs" and "manwho-solves-problems" only represent a tripartition that acts as a didatic artifice for the study of man. In other words, according to the author, in psychology "there exists only one individual - who perceives and struggles and thinks" (i.e., an individual who is characterized by having a "pattern of perceptions, motives, emotions and adaptive behaviors" that "is unlike the pattern of anybody else"). Within this context, the writer, as an individual, is a unique being highlighted in the uniqueness that conjugates the human ensemble of individuals. His world is made up of what he perceives, feels, sees, thinks and imagines in a manner that cannot be identically reproduced by any other person. The world, perceived in this manner, precedes the writer's linguistic creation, primarily making him think with his senses. As a consequence, the individual perception of a writer is his thought, his invention, an observation about what is perceived.

In turn, as a type, a writer has his personality taken into considerations (i.e., his traits, skills, beliefs, attitudes, values, motives, forms of adjustment and temperament, his outer aspect), 
the way he is perceived by others and influences them, are analyzed and often generalized as a "scheme of understanding", used here as an expression by Eduard Spranger (1928). The traits are in the person; the types in an external viewpoint. Thus, for example, according to the particularities of each classification, there are philistines versus bohemians, apollineans versus dyonisiacs, and rationalists versus empiricists. Spranger, when focusing his analysis on fundamental human values, admits theoretical, aesthetic, social, political, and religious types. It is not that a person fully belongs to one of these types, but rather we may understand a person by examining his values through these denominations.

It should be emphasized that, as abstractions created to support these schemes of understanding, none of these typologies explains the individual as a whole. There are authors who advocate the use of ideal types (derived from rational methods such as those of Spranger), and authors who advocate the use of empirical types (which presume to cover a broad area of personality of many persons, extremes of a continuum, such as introverted versus extroverted individuals); cultural types (influenced by their participation in groups, whether typical or dissident, such as a trader, a farmer, a barber, a priest, a politician, etc.) and propedeutic types (who introduce basic knowledge about a topic, such as constitutional, perceptual, cognitive, maturity and immaturyty types etc.). However, although being a type who is part of a social group, a personality is regulated by traits (i.e., by its active nature which resides inside the individual and not in his profession).

When dealing with the question of types in Psychology, Allport (1969, pp. 35-36) clarifies that this "is a partial approach to individuality" which often seeks generality and amplitude, (i.e., the possibility of classifying a type as a "liberal, narcisistic, cerebrotonic, or authoritarian" person, among others), in order to find an "ample and valid categorization of human beings". However, still according to the author (p. 438), "starting from types, researchers often reach useful information about complex traits and nothing more than that".

\section{The Study of the Creative Process}

In the Houaiss and Villar dictionry (2001, p. 868 ), the term "creation" is defined, among other meanings, as the process or effect of conceiving, inventing and generating by means of a human, divine or similar superior force what does not exist, and to give a new form and a new use and to improve something that alreday exists. An intellectual product par excellence since it requires the exercise of reasoning and of the skills needed to execute complex tasks, creation, according to Sartre (1996, p. 150), urilizes the imagining of types of consciousness which, united in a logical sequence, "will produce a sort of life for the object as an image", appearing in one aspect or another according to what man perceives through his senses:

Judging that a coachman whose face we represent in an obscure maner has mustaches is seeing his face appear with mustaches.... If, in the imagining mode, we think of individual objects, these will be the same objects that will appear to our consciousness... Actually, it is rare for us to think of a an isolated class. Most of the time our thoughts are the establishment of relationships between classes. (Sartre, 1996, pp. 150-151)

In Sartre's conception, therefore, the descriptions of types, environments, sensations and emotions detectable in literary texts place us in front of a symbolic system whose understanding is a movement that is never concluded but in whch the symbologies are continuously sought for the progress of knowledge. However, this imaginary conceived by common sense differs from the collective imaginary, in which it is the subjectivity of a person that is presented to the unconscious, and differs from the personal imaginary in which the images of a people and of a culture are presented to the reader. In turn, the collection of subjectivities and cultural images of a people is conceived by Durand (2001) as a response to the human anguish in the face of the finitude of life (i.e., man needs to delineate an athropological path that will constantly reaffirm for him his ability to create and perceive realities). 
The E-Dictionary of Carlos Ceia (n.d.) states that the "imagination" entry derives from the Latin imaginatio, which in turn replaces the Greek phantasia. According to Ceia, imagination, as early as stated by Aristoteles (trans. 2006) in the De Anima (428a 1-4), consists of the mental process through which we conceive an image (phantasma) since, according to Aristoteles, the human mind is unble to think without images, representing with them what does not exist in our immediate world. As explained by Ceia, the original Greek meaning of the concept, maintained in the German term Phantasie, refers to what is present in the first great theoreticians of the subconscious, Freud and Jung, corresponding to how they always used the term. In turn, literary studies of the 18th century emphasized the creative power of imagination as an essential activity of artistic creation, in clear opposition to its meaning in Antiquity (i.e., an exercise considered similar to feelings of melancholia, nostalgia, fear, and boredom). This idea that it is necessary to feel to be able to imagine will not represent for Plato a way to achieve knowledge, but rather a way to obtain a sort of second-hand copy of reality. This argument was taken up again by Descartes (1986, pp. 31-32) in his Discourse of the Method, when he stated that "neither the imagination nor the feelings could ever permit us to certify anything without the intervention of the understanding".

With the European romanticism, which attributed to imagination the status of a subjective alternative in order to achieve less pragmatic forms of knowledge, and with the questions raised by Kant, which admitted imagination as the synthesis of human perceptions to which the images that represent them are proposed, a new theory of imagination was established, whereby imagination was proposed as a privileged pathway towards subjective knowledge at the expense of pragmatic knowledge. Within this context, Coleridge, one of the creators of romanticism in England, by admitting that the full vitality of the senses can be experienced only through imagination, elevated the latter to the creative power of God. This opinion was shared by the German philosopher Schlegel, who un- derstood imagination as the ability to associate images at the consciousness level, in contrast to fantasy, which appears to operate with images arising from the frontier with the unconscious. The 20th century, however, revealed a greater interest in the product originating from the creative imagination, highly approximated to personal experience, than in its theorization.

According to the German psychologist $\mathrm{Ru}-$ dolf Arnheim (1974), it is the task of creative imagination to enable man to translate the physical appearance of objects into appropriate forms for given contexts, this being due to the psychological reason that, in the human perception and thinking, the similarity is not based on a meticulous identity, but rather on the correspondence of essential structural characteristics. However, according to the author, something new is only valid up to the point it serves to interpret a universal topic of human experience. Using works of art as examples of what can be perceived by man through his vision, the behaviorist Arnheim (1974) conceived that, since it is dynamic and not static, an image does not represent arrangements but rather interactions of its own tensions, leading to the reasoning that it is not the eye that constructs the interaction of objects in a visual field, but rather that it is the dynamics of shapes that determines how this visual field is perceived. On this basis, defining a work of art as an expressive form created for our perception through the senses or the imagination expressing human feeling, as done by Susan Langer (1957), is highly acceptable on the horizon of literary studies.

Regarding the creative process in the literature, Wellek and Warren (1949) proposes that modern studies may be closer to the relative role played by the conscious and the unconscious, since a writer is a specialist in the association (ingenuity), dissociation (judgment) and recombination (creating a new whole from elements experienced separately) of words, which he considers to be valuable symbols of themselves or in terms of what they represent. In this case, assuming that the creation of characters consists of a fusion of inherited types, observed types and the type represented by the author himself indicates 
that only the "ego(s)" as potential material for literary creation can become complex characters. Nevertheless, psychology can also study the various methods of composition, correction and rewriting practiced by writers. The usefulness of this? To discover gaps that will permit the writer to probe what occurs in his laboratory of artistic production and to inhibit inconsistencies and distortions in the work of art he intends to create, although always being aware of the fact that, even though these are practices of creation, they do not belong to a work of art, but rather to its elaboration.

It is definitely possible to state that fictional characters appear to be psychologically true, especially in cases in which the author has sought in psychology the figures and interpersonal relations he has used in his work of art. But these characteristics overlap so constantly that the complex situations in which they are involved and on which they act deserve more acute observations than the possibility of fitting them into a specific social type. An example of this is represented by works constructed using the stream of consciousness technique. In these works, a faithful reproduction of the mental processes presented is less relevant han the possibility of dramatization offered by the technique used. In other words, it is not the psychological truth, regardless of the emphasis on the notion of the reality of creation, that will give artistic value to a work of art, but rather the way this truth was manipulated to underscore coherence and complexity so that something really new is obtained.

\section{The Study of the Types and Laws Present in Literary Works}

The Study of Types. In literary studies, the type is investigated as one of the possibilities of a character to be created. A schematic configuration both in a physical and psychic meaning, projected as a "real" fully determined individual, as well as one of the three essential structural elements of a novel, the type, according to Forster (1974), is one of the characterizations of plane, linear characters defined by a single trait that does not change throughout the work. A com- mon practice in historical novels, the presence of the type, according to Kaufman (1991), is justified by the necessity of the extistence of representatives of a given milieu or social class in whose fictional destinies are reflected important trends and historical changes.

By representing society or a specific social group, their literary construction becomes possible, among other aspects, thanks to the attention placed by the author on the meaning of his words and to the practice of orality established by this attention between locutors and interlocutors in the plot of the text, which guarantees the important linguistic and imaging representation for the insertion of the characters in the universe of a determined epoch. As plane characters, their role is tied to a specific situation or to a generalized conduct, a characteristic that also distances them from caricature, which involves a unique quality or idea taken to the extreme, so that such distortion purposefully evokes a satire. Thus, identified by their profession, behavior and social class (i.e., by a distinctive trait common to all the individuals of a same category, the characters would represent, for example, the good man who defends social values, the evil man who defends evil deeds, the older man who knows how to give advice, and so on, all of them having in common an interiorized competence).

The Study of Laws. It is certainly possible to use psychology to clarify the interpretation and valuation of literary works, and it is also possible to proceed in the same manner regarding sociology, philosophy, history and other disciplines which, supported by their theoretical constructs, can help the reader to understand the fundamental concepts that may have been used to elaborate a literary plot. Mario Valdés (2004), favorable to the existence of a limited field of interpretations at a given point in the narrative, believes that the interpretation mediated by the diversity of the fields of knowledge should highlight the meaning of the text and communicate this meaning in relation to others, transposing it from the subjective domain to the intersubjective domain. It is by attracting a language that is appropriate for the production of meaning that a literary work, as it exercises the principle of syn- 
thesis, provides a communicable language and becomes able to be mimetic.

Jean Bessière, a French scholar studying literary facts (1995), recognizes that in the literature, regardless of the kind and form it adopts, there is the ability to represent a content that cannot be dissociated from the world or from history, or from their respective corresponding elements in the world of imaginary references. However, Wellek and Warren (1949) alerts to the danger of directing one's investigative interests at drafts, rejected versions, exclusions and other original cuts made by the authors: despite the stylistic understanding we may acquire about their author, these products no longer belong to the work of art under analysis, nor do they value what is concrete in what was literarily created.

Specifically used to deal with what one or more criteria cause something to be considered literature, the term literality, defined as a fictitious discourse or the imitation of daily language acts and in relation to certain properties of language (Culler, 1995), has theoretically and methodologically relevant aspects of the literary object. By representing reality or by self-representation, a literary work may show realistic intentions, with a character being dentified as a social individual; conventional semantic intentions with the text acting as a mediator of the instances that occur in the narrative; simulation intentions, in which what can be said or not said is always indirect; and social symbolization intentions, with the narrative involving a consideration of the manner how society symbolizes itself.

According to Proença (2001), the relationship between literature and specificity, as well as questions involving complexity, multisignificance, the predominance of connotation, the freedom of creation, the emphasis on the significant and the variability, for example, are characteristics of the literary discourse that guide this study universe in a peculiar manner, accounting, as rules, for the modes of literature creation as prose and as verse. This presentation of fundaments for a theory of artistic production, however, deserves a specific discussion, such as that performed by Bordieu (1996), which is beyond the purposes of the present study.
The Study of the Effects of Literature on the Readers. In his work "The Act of Reading" (1996), originally published in 1976, Wolfgang Iser conducted an important study of the interaction between the reader and the text focusing on how, and under which conditions, a text has a meaning for the reader. Since the traditional interpretation intended to elucidate hidden meanings, Iser wanted to see the meaning as the result of an interaction between text and reader, as an effect that is felt by the reader and not as a message that must be found in the text. In other words, according to Iser, the texts, in general, contain statements that can be understood by the reader mixed with other statements that require from the reader a complementation of meaning, a filling of their "gaps" (i.e., of what they do not state explicitly). This active complementation by the reader causes him to wonder at any instant whether the formulation of the meaning he is performing is adequate for the reading he is carrying out. And it is by means of this condition that the interaction of the text with the reader occurs, something quite different from reading the text looking for a hidden message or based on a unique interpretation.

Roman Ingarden (1979) provided a useful explanation for this investigation, stating that the aesthetic object is constructed only through the act of cognition by the reader. By adopting this precept of Ingarden, Iser (1979) exchanges the focus of the text as an object with the text in potential, born from the results of the act of reading. In order to examine the interaction between the text and the reader, Iser looks for those qualities of the text that render it legible, deserving to be read, or that influence our reading, as well as the charactistics of the reading process that are essential for the comprehension of the text. In his initial work in particular he adopts the term "implcit reader" in order to encompass both functions. This resides in the structure of the act and in the textual structure. Later, with a more in-depth dependence on the terminology of Ingarden, he differentiates text, concretization of the text and work of art. The first differentiator beween the text and a work of art is the artistic aspect, which is located here by the author for 
us to read, and which must be better conceived as a potential expected achievement. The concretization of the text, in contrast, refers to the product of our own productive activity; it is the realization of the text in the thinking of the reader, achieved by filling out the blanks or openings in order to eliminate what is indeterminate.

Finally, a work of art is not a text or a concretization, but is something between them. It occurs at the point of convergence between the text and the reader, a point that is never fully defined. A work of art is characterized by its virtual nature and consists of various overlapping procedures. One of them involves the dialectic of protention and retention, two terms borrowed from the phenomenologic theory of Husserl (1986). Protention is understood as the state of expectation that prepares the reproduction of a memory (i.e., the pre-memory, and retention is understood as the primary memory brought to us by the text we have read). It is through ptotention and retention that the texts duplicate, moving from the original texts to new works in the presente. Iser (1979) applies them to our activity of reading successive sentences. When facing a text, we constantly project expectations that can be satisfied or disappointed; at the same time our reading is conditioned by the renunciation of sentences and concretizations. Because our reading is determined by this dialectic, the basic activity of the reader, according to Iser, resides in the constitution of the meaning stimulated by the text, with this meaning taking shape through the connection of the constitutive elements of the text and of its articulation and combinations responsible for its coherence and cohesion. According to Iser, it is by filling out the gaps and the blanks of a text that the reader will reach its meaning. The gaps and blanks should be understood as everything that was not said explicitly in the text but was only tacitly suggested. This involvement with the text is seen as a type of tangle in which what is strange will be understood and assimilated. Iser's (1979) viewpoint is that the reader's activity is similar to an ongoing experience.

The same author states that, by filling these "gaps" (i.e., by attributing meanings to what we are Reading), we simultaneously reconstruct ourselves as long as our meeting with literature is part of a process of understanding the other and ourselves in a more complete manner:

"Às the gaps indicate a potential relation, they free the space of the positions denoted by the text toward the acts of projection... of the reader. Thus, when this relationship takes place the gaps disappear" (Iser, 1979, p. 106).

However, Iser (1976/1996) does not rule out the possibility of failure of communication and dialogue (i.e., if equilibrium becomes possible by filling the gaps through the projections of the reader, this interaction may fail or the projections of the reader impose themselves regardless of the text). Thus, Iser (1976/1996) believes that the basic activity of the reader resides in the constitution of a meaning stimulated by the text, which comes from the connection of its constitutive elements, of the articulations and of the necessities of combination, responsible for the cohesion of the text by the filling of its gaps. The gaps also interrupt a good continuation (i.e. the desirable continuation), supporting the activity of composition of the reader. The reader must recur to his imaginative activity in order to establishe the meaningful coherence of the text.

Constructed in this manner, the horizon of expectations of the reader undergoes additions of new reading expectations through the reader's interpretation of the text he is reading. However, if the reader refuses these interpretations of the text on the basis of the ideological positions he may hold, he will have difficulty in identifying what it has been agreed to call, in the Aesthetic of Reception, the implicit reader (i.e. the addressee considered by the text as a strategy). Thus, Iser (1976/1996) develops a theory of the aesthetic effect which leads to the constitution of a meaning on the part of the reader based on transformation processes, describing fiction as a structure for communication. The fictional repertory, the textual strategies, the variants of reading, the implcit reader and the gaps of the text are processes that complete the perspective of the text in itself and its reception by the reader, whose space is guaranteed in the studies of his critical successors. 
By considering that a major work of art always includes a vision of the world that, whether discussed or denied, is an integral part of its meaning (2003), Dante Moreira Leite seeks to present some questions about literary works for which contemporary psychology has its own perspective, differing from the perspectives of other sciences and of literary criticism itself, such as imitation,suggestion, the peception of shapes, the description of characters, the learning of taste, among others, although without aspiring to the presentation of a general or total solution for its analysis. What is the legitimacy of this process? According to the author (2003), it is the necessity to explain art based on the characteristics of an individual once the loss of social belief in the supernatural is recognized, as well as the loss of belief in the hereditary determination of individual characteristics and in sociological explanations as the origin of these differences. And, starting from Romanticism, a more marked subjective tendency towards artistic themes and towards interest in criticism is added to these facts.

\section{Psychology in Literature}

\section{A Psychology as a Perspective for the Reception of Literature}

Leite (2003) believes that, in the creation of a work of art, the author goes beyond the superficial and apparent aspects of everyday life reached from a historical and sociological perspective in the search of what, by being expressed about the human psychological condition, will continue to be valid in highly diverse situations. Within this context, significant contributions of contemporary psychology such as the description of the behavior and inner experience of an individual as a spontaneous activity, the continuity between the different degrees of problem solving and of the creative capacity and the attempt to interpret the unconscious life through dynamic forces are relevant resources in the attempt to explain the creation and permanence of a literary work.

However, the application of psychological concepts to an analysis of a work of art should be guided by the possibilities of the explanations that such concepts have for this task (i.e., by the applicability of these concepts as resources for the understanding of productive thought, without forgetting their limitations). Considering the organism-environment relationship, the relationship between affective life and intellectual life and the relationship between unconscious processes, Leite (2003) reflects about fundamental concepts of the theories of Freud, Jung and the gestaltists in order to clarify to what extent these concepts are useful for the description of procsses of productive thinking and/or the analysis of texts and readers.

Based on the definition of libido by Freud as mental life characterized by the search for pleasure, for love (Eros) and distancing from pain and death (Thanatos), and of the "Id" as the most profound and primitive art of the personality and "Ego" as the part of personality in contact with reality, Leite (2003) indicates these cpncepts as a framework for the focalization on literary analyses between organism and environment. In this case, the permanence of childhood feelings or events in the mental and behavioral life of adults, as well as the evolution of emotionl and affective conflicts in historical continuity, with repression of instincts in proportion to neurotic intensification, are relevant aspects for the approach to individual histories and cultural histories, respectively.

In agreement with Freudian theory, these manifestations in literature are only "different forms of equal conflicts" in a civilization in which "neurosis" is often an alternative way of expressing creative conflicts which, if barred, become distorted as abnormalities and conflicts of expression. For example, Edgar Allan Poe (1974), adopted together with his siblings by prosperous Baltimore merchants, by manifesting interest in productive thought at the expense of business profitability, elicited the displeasure of his adoptive father, who wanted him to continue the prosperity of the family. Thus, he grew up feeling that he was rejected as a writer, a fact that not infrequently had a direct influence on his obsession for the subject of suffering caused by death. In turn, Kaufhold (2008), in a study analyzing fact and fiction regarding Poe's sanity, 
pointed out psychological, biological and sociocultural human disorders such as anxiety, somatization and dissociation, among others, which, being detected in all cultures and in the most different times, although with different names, permit the readers to observe that they are increasingly able to repress instincts, a fact known to anthropolgists and sociologists in their studies of civilizatory processes of adjustment.

However, the fact that Freudian theory rests on the interdependence between affective or emotional life and rational life, a characteristic that contradicts current beliefs which assume continuity between the two, and on the rationalization of the problems presented by man in his environment in order to show the emotional and conflicting origin of the processes of human thinking, unmasks and destroys the human illusions, whether religious, sentimental or artistic, a fact that limits this theory regarding the analysis of creative thinking. Within the context of this theory, the concept of "unconscious", dynamically and continuously linked to conscience in a cause-effect relationship, and the Freudian attempt to translate it into intelligible terms have been considered to be one the most significant contributions of psychology to literature, especially for those who, like the German romanticists, were concerned about "the nocturnal and sick aspects of the human personality". However, as the experimental confirmation of this concept continued to reach increasingly scientific criteria of verification, being more accepted by scientists, its tendency to identify the same conflicts in all works of art rendered it reductionist and less accepted by writers and art critics.

Jung, considering the Freudian concept of "libido" to be a sort of vital internal "energy" for existence, raised the proposal that libido may take two innate directions corresponding to the subjective-objective and internal-external dichotomies that would respectively result in the introversion and extroversion of being. In addition, he proposed new concepts for the description of the individual, who he called "I", such as "external world"/"interior world", "personal conscience" (life experience)/“collective unconscious" (ancestral experience), "archetypes" (symbols or images existing in the collective unconscious which represent the structures of all things that exist), "persona" (superficial part developed as a response to environmental requirements), "animus" (male soul existing in the intimate part of every woman), "anima" (female soul existing in the intimate part of every man), "ego" (the conscious part of the personality, i.e., our 'I'-'we'), and "shadow" (qualities and tendencies that, refused by an individual as being his become parts of the individual unconscious).

The value placed on mysticism and religiosity and the recognition of unconscious forces that project into the external world and generate rich and significant ideas in productive thought caused Jungian theory to become a fertile ground for the development of the diversity of works of art, considered by artists to be a more profound and revealing horizon than the technique and knowledge of the exernal world provided by Freudianism. In "Capitães da Areia" (Captains of the Sands) a novel by Jorge Amado (1944) that tells the story of a group of abandoned boys left to ther own devices in the city of Salvador, each member of the groups has a highly symbolic identity directly proportional to the Jungian notion of archetype (i.e., the innocence/ perversity dichotomy, the heroism of the "childhero"/divinity and of the "child-god", protection/abandonment, fragility/invincibility, past/ future, among others). All of them to be added to the author's considerations about the four intellectual functions such as thinking, feeling, perception and intuition, that can be characterized according to their appearance in introverted and extroverted subjects.

In turn, the geltastists, in their perceptual studies that admit behavior as the result of an organism-environment interaction, opt to work with fields of force acting in various directions, able to organize and reorganize themselves continuously, alternating resting states (organized) with search states (reorganized) in order to reach an objective which, once ceased, redirects the subject towards new focalizations. The advantage of this type of analysis? It is the ability of the analyst, starting from successive states of balance and imbalance, to be able to study the 
organism exactly at a given moment, being concerned with the history of this organism only if this history is identified as an active force at the time under consideration.

What is the difference between the geltastists and Freud and Jung? The opposition of the mechanical model based on "energy" of the latter to the electricity model based on "force fields" of the former. Also, the geltastists, in contrast to the psychoanalysts, study cases in which behavior is directed by the environment and not by the impulses of the organism, although without isolating behavior and experience, a fact that would render this study inviable. In other words, according to Leite (2003, p. 36), while Freud and Jung "assume that man is a being impelled by unconscious forces of an affective character", for the gestaltists "behavior seems to be fundamentally determined by an "intelligent" contact with the environment", leading to the following:

"psychoanalysists endeavor to discover or reveal the irrational aspects underlying an apparently rational behavior, while gestaltists try to detect characteristics of rationality or adequate perception even in emotional behavior" (Leite, 2003, p. 37).

This difference becomes more explicit during an analysis of productive thought in the literature, with psychoanalysts being able to do it in art, but not in science or technique, whereas the geltastists explain the creative thought in science but, when focusing on art, they emphasize aspects linked to perception and not to literary art. What is responsible for this? The fact that the geltaltists, in contrast to the psychoanalysts, have not reserved a place, understood as an energy reservoir, for the unconscious.

Finally, even though a group of psychologists, among them the German psychologist Hans Jürgen Eysenck, believing that the singularity of personality is equal to that of other objects and that the description of an individual is nothing more than a peculiar combination of characteristics shared by everybody, denied the necessity of a theory of personality, such theory arose. This theory emphasizes that the singularity of an individual (i.e., what distinguishes him from any mode of being human other than his own), permits the discussion of questions that are still currently debated such as whether the personality exists "in" an individual rather than in something that at a given time the analyst will be able to describe and which is stable in time and space. In the first case, while, according to some, the "unit" of an individual is something to be sought, according to others, several personalistic systems may exist as long as their descriptions are scientifically useful. In the second, with the organism-environment relationship taken to its extreme, the concept of personality would be that, as a set of characteristics, personality does not depend on the context in which an individual is inserted.

In geneal, Leite (2003) clarifies that, with the exception of pathological personalities locked up in their on worlds and of depersonalized individuals, who reflect the conditions in which they find themselves, eliminating the importance of the context for personality elicits a reducing focalization on it, without considering, for example, individuals who are able to adjust or to react in a realistic manner without being changed by the reality of the environment in which they are inserted and exist. Also (Leite, 2003, p. 39) personality is the concept of "unit" that manifests in all aspects of an individual's behavior and experience... which permits us to identify and describe a person among all others". The refinement of the descriptions of personalities, according to Leite, is often based on literary descriptions or on descriptions of persons who, not yet described by specialists in psychology, add much value and content to the studies of these specialists. In parallel, heredity has been superimposed on previous or temporary experience, causing behavior to be understood as the result of an interaction with the environment. Skinner and Watson, behaviorist psychologists who tend to explain all behaviors through learning, are examples of this.

Considering that the behavior results from this organism-environment interaction, Leite (2003) proposed that current psychology should have resources that will explain two forms of behavior that are of direct interest to literature (i.e., creative thought and the reading of a liter- 
ary work). If we examine the adequacy of psychology to explain these two behaviors, we will clarify the occurrence and concretization of the attempt of the psychologist and the fiction writer to present a convincing description of a person and of a character.

\section{The Creative Process: Reception and Response to the Environment}

According to Dante Moreira Leite (2003), traditional psychology used to understand human behavior as something resulting from mental life. Within this context, there would be a causal relation between conscience and behavior (i.e., a behavior would be considered to be determined by what man is thinking). However, contemporary psychology proposes that conscience should be understood as an intermediate link between environment and behavior (i.e., man is influenced by the environment and by his own idiosyncrasies when emitting a response to his milieu). On this basis, various psychological theories utilize different schemes in order to explain behavior. The simplest among these psychological theories seems to be the behavioral theory, whereby the response results from the environment (i.e. from stimuli, and the model that explains it is the conditioned reflex through which the stimulus-response linkage occurs). This theory is identified by the E-R model (i.e., the stimulus-response theory). With behavior being the result of this organism-environment interaction, Leite believes that current psychology should have the resources for explaining two forms of behavior that are of direct interest to Literaure (i.e., the creative thought and the reading of a literary work). Since the interest of the present study is in the behavior elicited by the reading of a literary work, we shall try to relate below a scheme of the E-R theory to the study proposed by us.

Considering what has been said thus far about the text, reader and expectation, we believe that it is possible to generalize, respectively, a stimulus, organism and respose model in which the text corresponds to the stimulus (E), the reader to the organism $(\mathrm{O})$ and the expectation to the response (R). This model is commony applicable in Psychology and may explain the creative thought and the reading of a literary work as being forms of behavior and experience, respectively. On this basis, we would have the following scheme:

\section{Text - Reader - Expectation}

Or

\section{S (Stimulus) - O (Organism) - R (Response)}

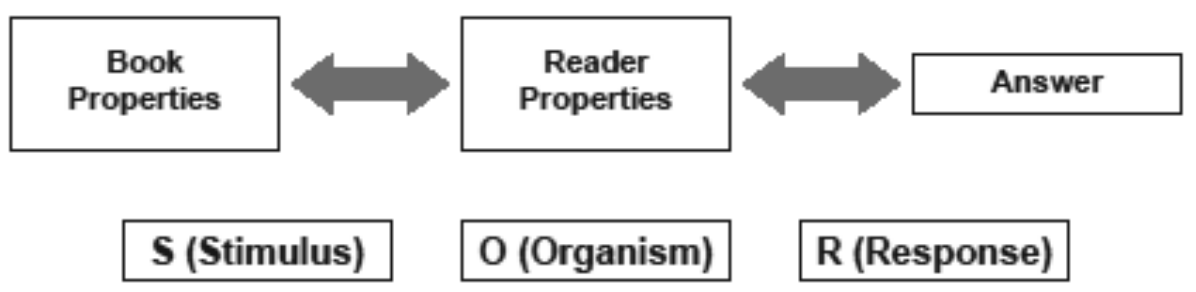

\begin{tabular}{|c|c|}
\hline $\begin{array}{c}\text { Interesting / Uninteresting } \\
\text { Innovative / Traditional }\end{array}$ & $\begin{array}{l}\text { Emotions } \\
\text { Personality }\end{array}$ \\
\hline & $\begin{array}{l}\text { Motivation } \\
\text { Wishes } \\
\text { Anxiety }\end{array}$ \\
\hline
\end{tabular}

Good Book

Bad Book

Figure 1. Text - Reader - Expectation or S (Stimulus) - O (Organism) - R (Response). 
The above scheme refers to perception (i.e., to the process whereby the reader is subjected both to the stimuli, represented by the properties of the book, and to his own characteristics as a perceiver, represented by the properties of the reader). Considered in this way, this scheme permits us to understand that the same work can be perceived at various levels, with different intensities, and mainly being susceptible to the idiosyncrasies of the reader. On the basis of the studies of Rozestraten (1988), and transposing them as far as possible to the study of the role of the reader in the literature, we conclude that at least three conditions are necessary in order to produce an adequate reading of a given work (i.e., the presence of stimuli or of situations; indicated by E) that can be observed and perceived: the book, an organism capable of perceiving and reacting adequately to the stimuli perceived (indicated by $\mathrm{O}$ ): the reader; a response to the stimuli that will identify how the organism behaves in the reading system: the opinion.

By connecting the elements of this scheme with one another, we understand that they are valid for a schematic representation of the process of textual reception. It should be remembered, however, that it is not a stimulus that provokes and determines the response of the critic, but that this response is also influenced by the organism with all of its previous experience and learning (i.e., there are subjective experiences of an entire life, all of them manifesting themselves in the reader). The cycle is continuous and its division into stages is only used to clarify its more important events and to render the explanation of the reading process as didactic as possible. Any interpretation is simply a way of revealing aspects of a determined work, always falling short of its total content.

We should remember, however, that specific focalizations on the creative process (i.e., not linked to the reception of the process, can be performed), according to Willemart (2009), on materials that surround the great writers, such as the tradition respected by them, the schools they attended, the time they lived in, their ideologies, prejudices and human mediocrities, which, in the constant search for an original content, cause the writing of literature to be the representative of a reconstruction of identity in which each resolved deletion in a progressive (re)construction of the identity and the works of the author.

\section{References}

Allport, G. W. (1969). Personalidade: Padrões e desenvolvimento. São Paulo, SP: Herder.

Amado, J. (1944). Capitães da Areia. São Paulo, SP: Livraria Martins.

Arnheim, R. (1974). Arte e percepção visual. São Paulo, SP: Edusp.

Bessière, J. (1995). Literatura e Representação. In M. Angenot, Teoria Literária: Problemas e perspectivas (pp. 379-396). Lisboa: Publicações Dom Quixote.

Bordieu, P. (1996). As regras da arte: Gênese e estrutura do campo literário. São Paulo, SP: Companhia das Letras.

Candido, A. (1998). A personagem de ficção. São Paulo, SP: Perspectiva.

Ceia, C. (n.d.). Imaginação. Retrieved from http://www.edtl.com.pt/?option $=$ com mtree\&task $=$ viewlink\&link $\mathrm{id}=412 \&$ Itemid $=2$

Culler, J. (1995). O que é literariedade. In M. Angenot, Teoria Literária: Problemas e perspectivas (pp. 45-47). Lisboa: Publicações Dom Quixote.

Descartes, R. (1986). Discurso do método. Lisboa: Livraria Sá da Costa.

Durand, G. (2001). As estruturas antropológicas do imaginário: Introdução a arquetipologia. São Paulo, SP: Martins Fontes.

Forster, E. M. (1974). Aspectos do romance. Porto Alegre, RS: Globo.

Houaiss, A., \& Villar, M. de S. (2001). Dicionário Houaiss da Língua Portuguesa. Rio de Janeiro, RJ: Objetiva.

Husserl, E. (1986). A Ideia da Fenomenologia. Lisboa: Edições 70.

Ingarden, R. (1979). A Obra de Arte Literária (2 ${ }^{\text {nd }}$ ed.). Lisboa: Fundação Calouste Gulbenkian.

Iser, W. (1979). A interação do texto com o leitor. In H. R. Jaus, A literatura e o leitor: Textos de Estética da Recepção (L. C. Lima, Trans.). Rio de Janeiro, RJ: Paz e Terra. 
Iser, W. (1996). O ato da leitura: Uma teoria do efeito estético (Vols. 1-2). São Paulo, SP: Editora 34. (Original work published 1976)

Kaufhold, J. A. (2008). The neuroses of Edgar Allan Poe: A fever called living. New York: iUniverse.

Kaufman, H. (1991). A metaficção historiográfica de José Saramago. Colóquio / Letras, 120, 124 136. Retrieved from http://coloquio.gulbenkian. $\mathrm{pt} / \mathrm{bib} /$ sirius.exe/issueContentDisplay? $\mathrm{n}=120 \& \mathrm{p}$ $=124 \& \mathrm{o}=\mathrm{p}$

Krech, D., \& Crutchfield, R. (1973). Elementos de Psicologia (Vols. 1-2). São Paulo, SP: Pioneira.

Langer, S. (1957). Problems of Art: Ten Philosophical Lectures. New York: Scribner's Sons.

Leite, D. M. (2003). A psicologia e o estudo da literatura In D. M. Leite, Psicologia e Literatura. São Paulo, SP: Editora da Universidade Estadual Paulista.

Poe, E. A. (1974). Biblioteca Universal Estados Unidos - Contos. São Paulo, SP: Três.

Pombo, O. (2005) Interdisciplinaridade e interação dos saberes. Liinc em Revista, 1(1), 3 -15.

Proença, D., Filho. (2001). A linguagem literária. São Paulo, SP: Ática.

Rozestraten, R. J. A. (1988). Processos psicológicos básicos do comportamento no trânsito. In R. J. A. Rozestraten, A. Psicologia do trânsito: Conceitos e processos básicos. São Paulo, SP: E.P.U.
Russell, D. H. (1964). Psychology and literature. College English, 25(7), 551-553. Retrieved from http://www.jstor.org/stable/373246

Sartre, J.-P. (1996). O imaginário: Psicologia fenomenológica da imaginação. São Paulo, SP: Ática.

Spranger, E. (1928). Types of men: The psychology and ethics of personality. Halle, Germany: Niemeyer.

Valdés, M. (2004). Literary Cultures of Latin America: A Comparative History: Confi-gurations of literary culture. Oxford, UK: Oxford University Press.

Wellek, R., \& Warren, A. (1949). Teoria da Literatura. Mira-Sintra, Portugal: Publicações EuropaAmérica.

Willemart, P. (2009). Os processos de criação na escritura, na arte e na psicanálise. São Paulo, SP: Perspectiva.
Recepted: 12/12/2016

$1^{\text {st }}$ revision: $14 / 01 / 2017$

$2^{\text {nd }}$ revision: $15 / 05 / 2017$

Accepted: 17/05/2017

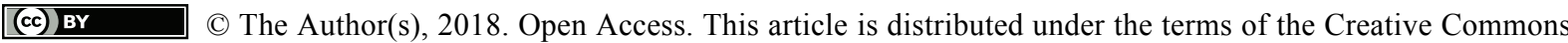
Attribution 4.0 International License (http://creativecommons.org/licenses/by/4.0/), which permits unrestricted use, distribution, and reproduction in any medium, provided you give appropriate credit to the original author(s) and the source, provide a link to the Creative Commons license, and indicate if changes were made. 